Copyright (c) 2010 Edward Elgar. This material is copyrighted and any downloads of this material are for personal use only. 


\title{
16. Learning from life experiences: a study of female academic leaders in Australia
}

\author{
Linley Lord and Susan Vinnicombe
}

There has been an increased representation of women within Australian universities. This is due in part to structural changes in the system and in part to equal opportunity and affirmative action legislation, policy and practices. However, gender equality has not been reached and universities continue to operate as highly gendered organizations (Currie et al., 2002; Eveline, 2004; Fogelberg et al., 1999). For women in academic roles some vains have been made. Their participation rate has risen from one-fifth of all acildemic staff in the mid-1980s to two-fifths of all academic staff nearly two decades later. Women, however, remain under-represented at senior levels with men accounting for more than 80 per cent of the most senior academic positions in Australian universities (Carrington and Pratt, 2003).

Overall women make up 30 per cent of university management positions. Women remain concentrated in discipline areas that are considered traditionally female so that there are both horizontal and vertical gender dillerences in the academic workforce in Australia (Carrington and Pratt, 20(1)3). During the period 1996 to 2003 the number and proportion of women vice-chancellors in Australia increased from 2 (5 per cent) to 10 (27 per cent) of all vice-chancellors. At the deputy vice-chancellor/pro vicechancellor and dean position level, however, the gains are considerably lower. There were 19 (19 per cent) women in 1996 at these levels and by 2003 there were 27 (21 per cent) (Chesterman et al., 2005). In 2004 only 16 per cent of professors were women (Winchester et al., 2005). It is common in many Australian universities for academic leadership roles such as head of school appointments to be offered on a 'contract' basis. That is, the leadership position is offered for a fixed term, usually three to five years. At the completion of the contract the position is usually readvertised. Thus the incumbent can potentially return to their previous school/department role at the end of the contract, either through their own choice or as a result of an unsuccessful application for a further term in the leadership role. 


\section{RESEARCH APPROACH}

The research took a phenomenological approach informed by feminist perspectives to contribute to our understanding of the lived experience of academic women leaders in Australian universities. Thirty-five in-depth semi-structured interviews were conducted and led to the development of a model of engagement and enactment of leadership. Insight was also gained regarding the context within which this engagement and enactment occurred. All of the women interviewed were in positions that the institutions regarded as leadership positions, that is, they had responsibility for financial and human resources. The data collection process was adapted from Creswell's (1998) cycle of data collection. A purposeful sampling approach was used to identify academic women who held formal organizational positions that included responsibility for human and financial resources. The research took place within the context of being an academic woman within an Australian university at a time when universities were under increasing pressure resulting from globalisation and national agendas for reform.

A set of interview questions acted as a guide for the interview process. The questions focused on how the women experienced leadership, seeking information on events such as a typical day, how they saw their gender impacting on their career and in their current role, and how they gave and received support as leaders.

\section{ENGAGING IN AND ENACTING LEADERSHIP}

The leadership experiences of the 35 women leaders were framed as a four-step model of engaging in and enacting leadership shown in Figure 16.1. 'Stepping' explained the process by which women entered leadership positions; 'settling' focused on doing the job and recognized the integral aspects of being a woman; 'strengthening' focused on the particular aspects the women saw as important to their enactment of leadership; and finally 'sustaining' focused on how the women were supported and given support in their role as leaders. In this chapter we explore how the women responded to the challenges at each of the four stages through lessons learned from personal life experiences.

\section{Stepping}

A key factor that prompted these women's decisions to enter leadership was the impact of role models. Overwhelmingly when role models

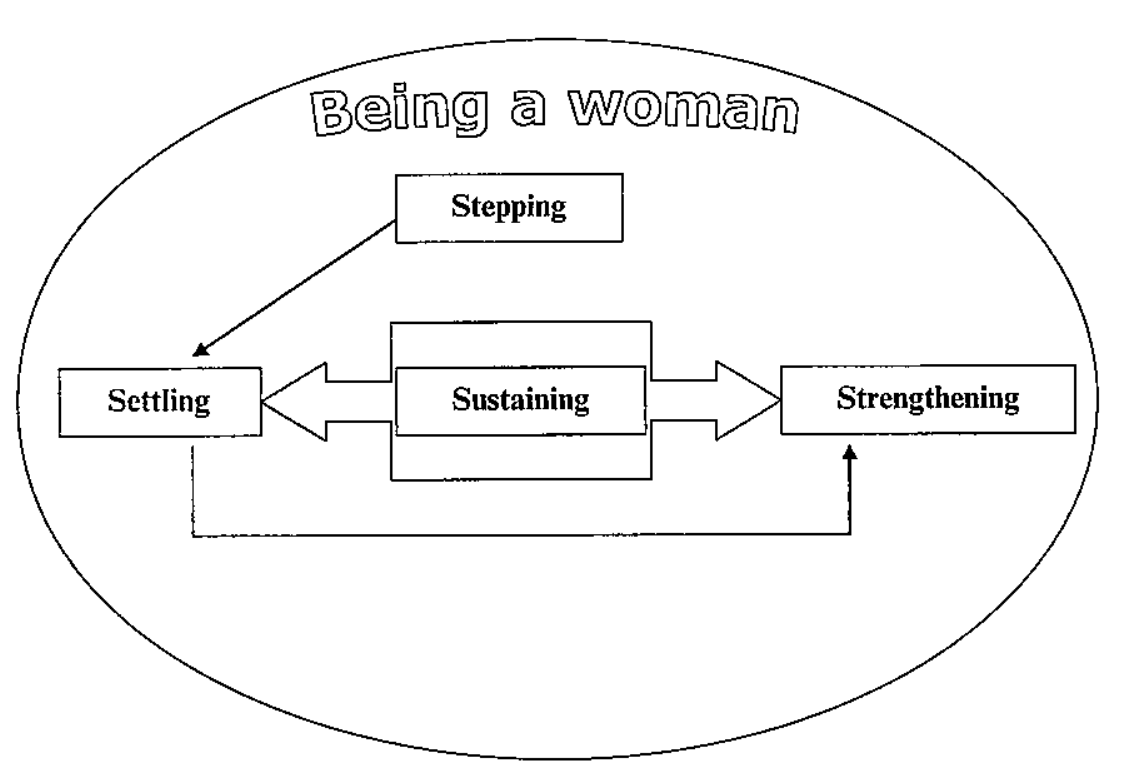

Figure 16.1 Engaging in and enactment of leadership

were discussed, they were male role models. This is not surprising given the relative under-representation of women in senior roles in Australian universities (Commonwealth Higher Education Management Services, 1998: Currie et al., 2002; Eveline, 2004). Moreover, it was the negative aspect rather than the positive aspect of male role models that was most often raised. For example, one woman's decision to enter leadership was the result of her experience of the then current incumbent who she saw as having 'no management skills whatsoever; less vision and was a bully'. This not only led to her decision to apply for the role but made her determined to be a very different type of leader. Another noted that she had:

watched these guys in positions and how they keep their positions of authority when they see people, you know, coming up because they feel threatened, and I'm thinking, and I've seen them do it and they do it in this sarcastic cynical, like put down way and I don't want to do that.

The absence of positive role models may explain why many of the women in this study had not considered taking up a leadership role until they were 'pushed', encouraged or told by others more senior to themselves to apply for a specific position. Senior staff, peers and friends played an important role in encouraging or 'forcing' women to step into leadership. This included being asked by peers who recognized their 
leadership potential or in some cases told they were needed by the dean or vice-chancellor, often in response to an organizational crisis. Friends who were external to the organization had encouraged some. Thus for most of the women it was a sense of being needed, either by the organization or by others, or their frustration they had experienced with current leaders that lead them to consider a leadership role. They felt pressured to accept the 'invitation' or had a sense of obligation to their peers. They spoke about their move into leadership roles as unexpected, unplanned and often accidental. Throughout their paid and unpaid work life they had consistently chosen work that was for them interesting and where they felt that they could make a difference. Being prepared to volunteer, 'whenever a volunteer is called for I put my hand up ... it doesn't matter what it is . . I think it is a new learning experience, probably won't do any harm on my cv" or for some to be volunteered, 'well it wasn't my choice it was a crisis situation' shaped their development as a leader. Their community work often provided the opportunity to develop their leadership skills further, 'I join something socially in the community, and I think, first thing you know I am going to be the President of something in the community. I know I can do that because I have organizational skills and I tend to speak up.'

Some had taken the steps to develop themselves professionally including being prepared to gain international experience that wasn't available in Australia at the time. This meant that for one woman she had:

educated myself or exposed myself to things that I thought I needed to know or know more about. Quite early on for example in my working life as a young professional, I needed a certain sort of work experience and I knew I couldn' get it in Australia at that time so I worked in the UK for a couple of years.

Thus leadership for most was shaped by the absence of positive role models and their ability to draw together the learning from various roles they had undertaken in paid and unpaid roles. Key characteristics of these previous roles were that they were interesting, had intrinsic value, and offered incumbents the opportunity to make a difference. In summary. these women's moves into leadership were rarely triggered through a desire to take on a leadership role but rather by the need for change or by others' encouragement or pressure to take on a particular role.

\section{Settling}

Once they had 'stepped' into leadership the women had to establish themselves in the new role. They were faced with a number of choices. They had to determine their goals and what style they would adopt and/or develop as a leader. Many didn't see themselves as leaders although their early experiences would suggest that others had seen their leadership potential and had encouraged them to undertake leadership roles: 'I suppose in a way I've always sort of had a bit of a leadership personality. I've been pushed into these positions right from the time I was in school into being captain of the hockey team.

Others, regardless of their earlier experiences, found that:

leadership was a concept that is utterly alien to me in that until sort of recent years and it has been my own reading on it that has developed my concepts of it but there is nothing in my career anywhere that I would consider even informed me or encouraged me to develop concepts of what is leadership.

Thus, for some, sport provided the opportunity to begin to develop their leadership skills and style. For others, leadership remained a somewhat 'alien' concept and it wasn't until they were in a leadership role that they reconsidered their conceptions of leadership and what it might mean for them as a leader.

A number of women commented on the lack of training provided, which meant that they felt unprepared for the role and faced a steep and often lonely learning curve. For most, learning the job and developing their style as a leader were concurrent activities coupled with the unrelenting pressure of the role, the hard grind that impacted on their energy levels and their feeling of being able to meet or attempting to meet the demands of the role. This added stress, particularly for those who were entering their first formal leadership role in the organization. However, there was for some a sense of surprise that, despite their feelings of unpreparedness, they were enjoying the role more than they had expected, and this helped them to continue making things happen and to meet the demands of the role.

Being a woman impacted on the way they did the job and how others saw them. Even if they tried to ignore their gender they were reminded by others of the impact that being a woman in a leadership role had and how it impacted on their being accepted as a leader in their own right. Early experiences of not being heard or taken seriously impacted on the type of leader women wanted to be.

I would say things at these meetings and it was like I hadn't spoken ... I got a very much feminist awakening of things. And then twenty minutes later a male would say the same thing and it would be jumped on as a marvellous idea. This idea 'Am I invisible? What's wrong with me?' It took me a while to figure out idea, 'Am I invisible? What's wrong with

This meant that they took active steps to ensure everyone's voice was both heard and acknowledged and became active mentors to more junior members of staff who were invariably women. 
Gender impacted on the way many of the women developed their operating style as leaders. For some it meant that their choices were often constrained by the views that others held about appropriate operating styles for women. However, for some it was the combination of being a women and an immigrant that really shaped their leadership development.

One that I was a woman, two I was an immigrant so I had a double situation. When I arrived I didn't speak any English ... I had a long tortuous road. So in other words, my start and my finish of what I was doing was so delayed so it was the combination of being a woman and an immigrant I believe. It is just one or the other. So when I was here I was absolutely dedicated. I locked everything out, just to educate myself. So I didn't marry, I didn't do anything. just to do that and I had to do that as a woman because if I had married or anything else I would have never got to this position.

Being an outsider in many situations meant that she became good at reading body language and observing what was going on around her. In her leadership role it meant that she was able to 'read' the situation more accurately and therefore was able to respond to situations more effectively both with her staff and engaging with those more senior in the institution.

Most women, as noted above, felt unprepared for the roles they had taken on and this had the potential to impact on the way that they wanted to develop themselves as leaders. One of the ways many responded to this was to use their networks to make the job somewhat easier, "I am quite instrumental. I know that you can build up a network and people will help you if you help them.'

Their networks provided a space that enabled them to test their ideas, get support and to get advice on a range of issues that they were confronting. For some, especially those who were at more senior levels, an externa network was seen as particularly important for many of the issues they wanted to discuss.

Settling into the role meant that women drew on the networks that they had established as an important means of both learning the job and providing them with some support. Through the experience of being either invisible or highly visible because of their gender, many had become skilled at effectively reading the situation they were in and had actively taken steps to ensure that their and others' voices were heard and acknowledged.

\section{Strengthening}

Being in a leadership role was more complex than just developing a style of leadership and undertaking a range of tasks that the particular university saw as appropriate for the role. Being transparent and consistent in their decision making was seen as an important demonstration of their integrity, and a signal to others about how they intended to do the job regardless of the toughness of the circumstances. How they went about managing change and making decisions was driven by their values. For some, early experiences of isolation followed by success in sport helped shaped the way they 'did' leadership.

I grew up in total isolation. I went to a one-teacher school and I had to start school when I was 4 because the school was going to close down and virtually I knew very few people until I went to boarding school. So I didn't have the opportunity to be socialized into thinking whether some things were appropriate for girls or boys to do and I guess I've always been a high achiever and I got, I suppose I got most of the feedback from that from being very good at sport. So my father for instance used to drive me all over the state for tennis because I So my father for instance used to drive me all over the state for tennis because I
was a state junior champion. And I suppose that sort of achievement gives you a lot of confidence about yourself which then prevents you from being - feeling like other people are threats to you or something.

The women willingly tackled long-standing issues and problems that included, in some cases, significant budget deficits, under-performing staff (even at a more senior rank), the quality and relevance of some teaching programs and under-performing research centers. A typical response was that they were committed to carrying out their roles properly, 'I suppose that's always been my approach, that if this is worth doing, I'll get in and do it 100 per cent'. In these various difficult situations some of the women realised that they were prepared to take risks, "what $I$ have discovered which is amazing, I would have described myself as a coward but compared to most of the boys I'm a risk taker'. For some it was the discipline of their doctoral studies that they believed had helped prepare them for demands of their role. As one noted, 'Ph.D. was the thing that prepared me for this. Like the training and the application and making you read ... the rigor of the Ph.D. I wouldn't be here today without that.'

The women expressed a strong focus on equity. They wanted to ensure that there was internal equity within the school or faculty and that staff and students were treated fairly by the systems that were in place or that they put in place. They wanted to act in ways that made sure that staff were not exploited, particularly junior academic staff who were more likely to be women. For some it was their earlier experience of sexual harassment or discrimination that had resulted in the strong focus on gender equity. Earlier experience of ongoing short-term contracts or insecure employment resulted in a determination that their experience should not be repeated, and as a leader they would do whatever they could to ensure others weren't treated in the same way. They did this even when this put 
them at odds with the university or when the expectation was clearly not to 'rock the boat'.

\section{Sustaining}

Having adequate support sustained the women, making the job of leadership easier. The women identified five main areas where they received support; the organization, a supportive boss, peers, family and friends. The organization was discussed in terms of the presence or absence of structural support such as adequate policies and procedural frameworks or appropriate levels of administrative support. Peers were divided into two groups. First, there are those that are at the same organizational level either within the institution or external to it and secondly, where the women were head of a school, they spoke about staff members of the school as peers.

Support from senior staff was available for some women and problematic for others. The lack of support ranged from a level of indifference through to bullying situations. Some had experienced what had at first appeared to be support:

The benevolent man is very dangerous because you don't pick it up for years. The person who tries to put you down and hold you down ... in my early caree I worked under two benevolent men ... and they supported and encouraged me, they were really pleased to take on my ideas, to take on whatever I had created, whatever new policy, whatever new processes.

Nearly all of the women commented on the lack of support they received from other senior women, something they found surprising and disappointing, 'I have been mentored by senior male colleagues at crucial times, no women.' Most had used peer networks for their support and some established their own support groups to ensure an effective support base, 'I am very good at networking and running my own support groups and I get all my support from below and support from across.'

Interestingly very few women spoke about receiving support from their family and/or partner. There were some who stated that they had been really well supported but for others, when they spoke about their partner, it was in relation to the support they gave in order to get or keep the support they were given, 'he's immensely supportive but I'm keenly aware that there is a sort of constant pay-off and the pay-off is that $I$ have to watch his ego.'

The demands of children presented a range of challenges for women who felt the burden of trying to be there for the university and for their children, my private life and my family life are incredibly important to me ... I have two teenagers and that complicates my life significantly ... I mean its not at all uncommon to be cooking dinner, listening to someone reading, talking to someone else about their school project having a phone call and trying to write an article.

However, having children meant developing certain skills, including the ability 'to do five things at once, it doesn't matter if the floor is filthy. . . it kind of grounds you' and not to worry as much about some of the things that don't get done.

Women received support from a range of people, both internal and external to the university and will build support networks if none are available. The support, however, was often conditional. It relied on them continuing to fulfill gender role expectations such as caring for others or taking major responsibility for running the home. A number of the women have also experienced lack of support from senior managers, peers and subordinates. It made their role more difficult and challenging as well as disappointing. Of particular surprise has been the lack of support they have received from other senior women and as a result they were more conscious, having moved into a leadership role, of the need to provide support to the women who reported to them.

\section{DISCUSSION}

Getting to a leadership position and determining how to be a woman leader continues to be challenging (Burke, 2005). For women there is the additional stress of being highly visible and often without the support structures of their male colleagues (Gardiner and Tiggemann, 1999; Kanter, 1977; Kerman, 1995).

In universities academic staff can move into leadership positions without having had managerial or supervisory experience. A strong research record is often viewed as a major requirement for leadership. However, being a good researcher doesn't necessarily provide opportunities for leadership development or relevant experience for roles that are increasingly managerial and driven by audit cultures in tight financial times (for Australian universities). Taking on a leadership role in such circumstances can be daunting.

Indvik (2004: pp. 292-3) suggests that women need 'resilience, perseverance, and initiative' to overcome the barriers and challenges they will face in organizations. For women, awareness of their gender, coupled with the lack of female role models, can act as limiting factors as far as developing their own leadership capacities, capabilities and styles is concerned 
(Ruderman and Ohlott, 2004). Little attention has been paid to the career experiences of women, how women overcome barriers to career advancement and that to understand women's careers requires acknowledging that women have fundamentally different career development situating (Hamel, 2009).

In her study on career transition and leader development, Gibson (2008) identified five themes relating to leader development. These were validation of self'; the power of shared experiences; direct feedback from those who know you; guidance freely given - modelling the way; and opening the doors - new learning (p. 658), and although each theme was seen as an essential aspect it was their combination that impacted on career development (p. 661). These themes resonate with the women's experiences. Despite rarely planning for leadership, key personal experiences helped the women to determine the type of leader they wanted to be and to develop skills that they found useful. Gender, negative male role models, personal networks and a supportive family all contributed to shaping the type of leaders they wanted to be and helped them to develop their own particular leadership identities.

\section{Role Models}

Role models have long been recognized as playing an important part in women's career development, as has the lack of women in senior roles who are available as role models (Eriksson-Zetterquist, 2008; Gibson and Cordova 1999; Quimby and DeSantis, 2006). People tend to seek role models who are similar to them in some identifiable way such as gender or race (Quimby and DeSantis, 2006). Given women's relative absence from senior roles, Eriksson-Zetterquist (2008) found that men were often mentioned as role models by both women and men, but women were seldom mentioned as role models, and when they were mentioned were seldom mentioned as

Thodels, and when they were mentioned it was only by females.

ented as polar models available in the public arena tend to be presented as polar opposites (Sinclair, 2004) which can be unhelpful for women trying to establish themselves as leaders. The models tend to be the 'iron lady' Margaret Thatcher mode, or the leadership 'saint' such as Mother Teresa who is seen as being 'all-collaborative, conflict avoiding, and endlessly empathic' (Sinclair, 2004: p. 14). Sinclair notes that these idealized types of women do little to reffect the reality of the complexity and multifaceted nature of women's leadership.

Role models are defined by Gibson and Cordova (1999: p. 123) as 'cognitive constructs created by observers ... with whom the observer seeks to enhance similarity based on his or her ideals, goals and needs'. Importantly they go on to point out that role models provide 'positive lessons of how to act' as well as 'negative lessons' of how not to act and have been seen as important in leadership development, particularly for women (Gibson and Cordova, 1999). Thus people focus on the traits or behaviors they wish to emulate as well as identifying the behaviors they wish to avoid (ErikssonZetterquist, 2008). In an earlier study regarding factors that facilitate career success, Vinnicombe et al., (2000) found that women directors had used role models to define both positive and negative behaviors.

Negative role models can be considered either as those who are seen as generally positive but they possess some traits that are seen as being negative, or those who possessed a majority of negative traits (Gibson, 2003). Gibson (2003: p. 598) identifies three aspects relating to negative traits, perceived dissimilarity, actions perceived to have a negative impact for the team or firm, and disidentification with the role model in that they wanted to differentiate themselves clearly from the negative role model. ErikssonZetterquist (2008: p. 268), in her study of role modelling in Sweden, noted that for women the construction of 'a role model was never complete: either the gender was wrong, . . . or the traits were not enough (childless women); or else negative actions made traits uncertain.' As a result women constructed proto-models on which to model their behavior.

In the absence of positive role models the women academics used the role models that were available to them, most of whom they characterized as negative role models, to create proto models that were useful to them. They disidentified with negative role models although they did see value in observing their behavior. It became their reference point for how not to act. They articulated a strong desire and took specific action to ensure that they would not be perceived as behaving in the same way. It was as Gibson (2003: p. 598) has noted that 'negative role models, though frequently disliked, were nonetheless considered useful for learning'. Ibarra has conducted research into how individuals in professional service firms make various career transitions, including from senior manager to leader. Most participants described how role models displayed the role identity they wished to emulate. This they saw as 'a possible self'. As with Gibson's studies Ibarra found participants who used role models to define negative behaviors - 'an improbable self'. This indicates the value of senior role models even if they are not attractive. She points out, however, that "the benefits of modelling styles and behaviors that do not feel very self congruent have not received much empirical attention' (Ibarra, 1999: p. 785).

\section{Gender}

In Kanter's seminal work Men and Women of the Corporation (1977), Kanter observed how the majority (men) dominate and marginalize the 
minority (women). In the book Kanter shows how women become tokens when in a numerical minority of less than 15 per cent - similar to the percentage of women professors in Australia. Even where the percentage hits a tipping point of 35 per cent, women continue to encounter discrimination at work.

Ely, in her study in 1994, looked at the impact of women's proportional representation at the top of organizations and what effect it had on relationships with other women in those organizations. She found that in ence gender as a positivenior women, women were "less likely to experito perceive senior a positive basis for identification with women, less likely likely to sorithe more likely to find competition in relationships with women peers, and less likely to find support in these relationships' (Ely, 1994).

Notwithstanding the problems facing women who are in the minority af executive levels, such experiences can make these women better leaders. Often these women emerge as leaders who are open, caring and nurturing of their team members. Their own experiences of being marginalized encourage them to be inclusive and ensure that everyone is treated equally in terms of rewards and promotion (Vinnicombe and pp. 273-80).

\section{Networks}

A key function of networks is that they provide support for career development (Mavin and Bryans, 2002). Tharenou (2005) has provided empirical support that shows that women are likely to face more barriers than men to managerial career advancement. The barriers include gender discrimination, existing male hierarchies and the lack of informal networks that promote and assist career advancement. The lack of access to informa organizational networks results in women's exck of access to informal sharing and alliance-building which impacts oxclusion from knowledge(Ibarra, 1993). Womenilding which impacts on their career progression of their additional caring have less opportunity for networking because of their additional caring responsibilities (Linehan and Scullion, 2008). by inorks are seen as important because of the social capital they build by increasing access to a range of potentially influential people and their 2007; Metz, 2009).

Women are less

(Morley, 1999), to likely to follow age-related linear career expectations to gain promotion (Chestermas much as their male counterparts in order to gain promotion (Chesterman et al., 2005) or to have had access to menexclusion from men's netw8). Cross and Armstrong (2008) suggest that internal and external to the organization, to develop their own communities of support where stories can be shared, identity formed and learning shared. Quinlan has also noted that in the absence of appropriate mentors or networks, women actively seek career supportive relationships with other women. Such relationships provide emotional, psychological and
social support (Quinlan, 1999).

Female networks can be a safe place for women to test with other women the meaning of their experiences and to develop their identity as leaders. They can be both internal, that is they occur within the organization, or external to the organization (Gibson, 2008; Metz, 2009). Despite their lack of access to formal and informal organizational networks, the women had developed effective networks, some of which were internal. These provided a means of 'collective learning' (Cross and Armstrong, 2008), and were a safe space for testing ideas, sharing career advice and challenging assumptions about the way leadership can be done (Metz, 2009). 'Collective learning' provided support for career development through increasing access to mentors and through the sharing of tacit knowledge (Cross and Armstrong, 2008: pp. 606-8). However, there can be an additional cost for women in having to maintain more extended and differentiated networks than their male counterparts (Hopkins and O'Neil, 2007) but as Marcinkus et al. (2007: p. 91) note, 'supportive relationships make career advancement and success more likely for women'.

\section{Work and Family}

There are continued and increasing tensions between the demands of family, however broadly or narrowly defined, friends and the organization (Winslow, 2005) and for women, who carry the major responsibility for families, the psychological conflict between these competing demands is often internalized and individualized (Belle, 2002). Tower and Alkadry (2008: p. 161) suggest that women face an unfair choice in that they are asked to choose between 'embracing work at the expense of family, or embracing family at the expense of career success'. Working women continue to face a greater challenge in trying to balance work and family commitments than their male counterparts (Grady and McCarthy, 2008; King, 2008).

Emslie and Hunt's (2009: p. 166) study of work-life balance in mid-life found that 'gender remains interwoven in the business of negotiating home and work life'. Despite evidence that men and women are increasingly defining career success in terms of work-life balance (Smith-Ruig, 2008), women remain caught in the double bind of social expectations regarding 
(Tower and Alkadry, 2008). Additionally women face pressure to also demonstrate leadership abilities whilst fulfilling gender expectations with respect to caring responsibilities (Tower and Alkadry, 2008).

Much has been written about the challenges for women of balancing work and family (see for example Pocock, 2003; 2005). Schwartz (1989) proposed the idea of two career tracks in organizations, one for those who were focused only on a career and one for those seeking to find some balance between their career and family demands. This second track was dubbed the 'mommy track' and being on this track impacted on career advancement. Some twenty years later some changes have occurred in the work-life balance debate, particularly in relation to men's roles as carers of family members (Galinsky et al., 2008). In their introduction to a special issue of the journal Gender Work and Organization focusing on work-life balance, Gregory and Milner (2009: p. 3) note that the existing literature focuses on three core issues, 'time management; inter-role conflict (role overload and interference) and care arrangements for dependents'. They also note, however, that even when work-life balance arrangements are in place in organizations, they are not extensively used. The mommy track has morphed into the parent track, and both women and men are reluctant to risk career progression in order to gain greater balance between the competing demand of family and the organization.

The research emphasis has been on women with young children (Emslie and Hunt, 2009) and on the negative impact that caring responsibilities have on women's careers. There has been less focus on how the demands of balancing work and family may help women develop skills that are usefully transferred to later leadership roles in the organization. Ruderman and Ohlott's (2004) study with alumni from the Centre for Creative Leadership's Women's Leadership Programme illustrates a positive association between women's varied life roles and effective leadership performance. They show how community roles, family roles and multiple tasking can offer rich lessons in how to handle the challenges of leadership. The authors suggest three important ways in which private life encourages and enhances leadership development. Firstly, it provides psychological strength. Secondly it provides the support of family and close friends who can offer encouragement and advice. Finally, out-of-work roles 'can be your laboratory for mastering management skills'. Ruderman and Ohlott conclude that drawing on all life experiences enhances and enlivens individuals and the way they carry out their leadership roles. Similarly the academic women in this study were able to point to the benefits to themselves as well as to their career that they felt they had derived from finding ways

\section{CONCLUSION}

To engage in and enact leadership, these Australian women leaders draw on their organizational experience, formal qualifications, and for some, formal leadership development opportunities. Overwhelmingly, however, they self-managed applying their life experiences. Although leadership for most was an accidental destination, they ensured that they personally accessed the resources required for the journey.

\section{REFERENCES}

Belle, F. (2002), 'Women managers and organisational power', Women in Management Review, 17(3/4), 151-6.

Burke, R.J. (2005), 'High-achieving women: progress and challenges', in R.J. Burke and M.C. Mattis (eds.), Supporting Women's Career Advancement, Cheltenham, UK and Northampton, MA, USA: Edward Elgar, pp. 13-30.

Carrington, K. and Pratt, A. (2003), 'How far have we come? Gender disparities in the Australian higher education system', available at from www.avcc.edu. au/policies_activities/university_management/uni_women_action_plan/gender_ disparities_\%20report_jun03.pdf, accessed 18 November, 2003.

Chesterman, C., Ross-Smith, A. and Peters, M. (2005), "Not doable jobs!" Exploring senior women's attitudes to academic leadership roles', Women's Studies International Forum, 28, 163-80.

Commonwealth Higher Education Management Services (1998), A Single Sex Profession: Female Staff Numbers in Commonwealth Universities, London: Association of Commonwealth Universities.

Creswell, J.W. (1998), Qualitative Inquiry and Research Design Choosing among Five Traditions, Thousand Oaks, CA: Sage.

Cross, C. and Armstrong, C. (2008), "Understanding the role of networks in collective learning processes: the experiences of women', Advances in Developing Human Resources, 10(4), 600-613.

Currie, J., Thiele, B. and Harris, P. (2002), Gendered Universities in Globalized Economies, Lanham, MD: Lexington Books.

Ely, R.J. (1994), 'The effects of organisational demographics and social identity on relationships among professional women', Administrative Science Quarterly, 39, 203-39.

Emslie, C. and Hunt, K. (2009), "Live to work" or "work to live"? A qualitative study of gender and work-life balance among men and women in mid-life', Gender, Work and Organisation, 16(1), 151-71.

Eriksson-Zetterquist, U. (2008), 'Gendered role modelling - A paradoxical construction process', Scandinavian Journal of Management, 24(3), 259-70.

Eveline, J. (2004), Ivory Basement Leadership, Crawley: University of Western Australia Press.

Fogelberg, P., Hearn, J., Husu, L. and Mankkinen, T. (1999), 'Hard work in the academy', in P. Fogelberg, J. Hearn, L. Husu and T. Mankkinen (eds), Hard Work in the Academy, Helsinki: Helsinki University Press, pp. 11-19. 
Galinsky, E., Aumann, K. and Bond, J. (2008), 'Times are changing gender and generation at work and home', available at http://familiesandwork.org/site/ research/reports/Times_Are_Changing.pdf.

Gardiner, M. and Tiggemann, M. (1999), 'Gender differences in leadership style. job stress and mental health in male- and female dominated industries', Journal of Occupational and Organizational Psychology, 72, 301-15.

Gibson, D. (2003), 'Developing the professional self-concept: role model construals in early, middle, and late career stages', Organization Science, 14(5), 591-610.

Gibson, D. and Cordova, D. (1999), 'Women's and men's role models: the importance of exemplars', in A.J. Murrell, F.J. Crosby and R.J. Ely (eds), Mentoring Dilemmas: Developmental Relationships Within Multicultural Organisations. Mahwah, NJ: Lawrence Erlbaum, pp. 121-42.

Gibson, S. (2008), 'The developmental relationships of women leaders in career transition: implications for leader development', Advances in Developing Huma Resources, 10(5), 651-70.

Grady, G. and McCarthy, A. (2008), 'Work-life integration: experiences of midcareer professional working mothers', Journal of Managerial Psychology, 23(5),
$599-622$.

Gregory, A. and Milner, S. (2009), 'Editorial: work-life balance: a matter of choice?', Gender, Work and Organization, 16(1), 1-13.

Hamel, S. (2009), 'Exit, voice, and sensemaking following psychological contract violations: women's responses to career advancement barriers', Journal of Business Communication, 46(2), 234-61.

Hopkins, M. and O'Neil, D. (2007), 'Women and success: dilemmas and opportunities', in D. Bilimoria and S. Piderit (eds), Handbook on Women in Business and Management, Cheltenham, UK and Northampton, MA, USA: Edward Elgar, pp. 132-54.

Ibarra, H. (1993), 'Personal networks of women and minorities in management: conceptual framework', Academy of Management Review, 18(1), 56-87.

Ibarra, H. (1999), 'Professional selves: experimenting with image and identity in professional adaptation', Administrative Science Quarterly, 44, 764-79.

Indvik, J. (2004), 'Women and leadership', in P.G. Northouse (ed.), Leadership Theory and Practice, 3rd edn, Thousand Oaks, CA: Sage Publications, pp.
265-300.

Ismail, M. and Rasdi, R. (2007), 'Impact of networking on career development: experience of high-flying women academics in Malaysia', Human Resource Development International, 10(2), 153-68.

Kanter, R.M. (1977), Men and Women of the Corporation, New York: Basic Books.

Kerman, L. (1995), 'The good witch: advice to women in management', in L. Morley and V. Walsh (eds), Feminist Academics, London: Taylor and Francis, pp. 131-44.

King, E. (2008), 'The effect of bias on the advancement of working mothers: disentangling legitimate concerns from inaccurate stereotypes as predictors of advancement in academe', Human Relations, 61(12), 1677-711.

Linehan, M. and Scullion, H. (2008), 'The development of female global managers: the role of mentoring and networking', Journal of Business Ethics, 83, 29-40.

Lord, L. and Pike, L. (1998), 'Not in our master's image: mentoring for change at Edith Cowan University; applications of the women in leadership model', paper presented at the Winds of Change Women and The Culture of Universities, Sydney.

Marcinkus, W., Whelan-Berry, K. and Gordon, J. (2007), 'The relationship of social support to the work-family balance and work outcomes of midlife of social Wumen in Management Review, 22(2), 86-111.

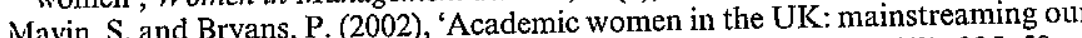
experiences and networking for action', Gender and Education, 14(3), 235-50. experiences and networking for action', Gender and Education, Metz, I. (2009), 'Organisational factors, social factors, and women'

ment', Applied Psychology: An International Review, 58(2), 193-213. York: St Martin's Press.

York. St What Work is doing to Austalians and

what to do about it, Annandale, NSW: Federation Press.
Pocock, B. (2005), The Impact of The Workplace Relations Amendment (Work

Pocock, B. (2005), The Impact of The Workplace Relations Amendment (Work
Choices) Bill 2005 on Australian Working Families, Adelaide: University of Adelaide.

Quimby, J and DeSantis, A. (2006), 'The influence of role models on women's Qurerly, 54, June, 297-306.

career che (1999) 'Enhancing mentoring and networking of junior academic Quinlan, K. (1999), 'Enhancing mow', Journal of Higher Education Policy and women: What, why and

Ruderman, M. and Ohlott, P. (2004), 'What women leaders want', Leader to Leader, 31, 41-7.

(Meader 31 ' Business Review, 67(1), 67-77.

Business Review, 67(1), 67-77.
Sinclair, A. (2004), 'Journey around leadership', Discourse: Studies in the Cultural Politics of Education, 25(1), 7-18.

Smith-Ruig, T. (2008), 'Making sense of careers through the lens of a path metaphor', Career Development International, 13(1), 20-32.

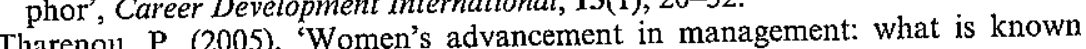
. Supporting and future areas to address', Women's Career Advancem

Tower, L and Alkadry, M. (2008), 'The social costs of career success for women', Review of Public Personnel Administration, 28(2), 144-65.

Romen with Attitude, London: Routledge.

Vinnicombe, S., Singh, V. and Sturges, J. (2000), 'Making it to the top in Britain', in in R.J. Burke and M.C. Mattis (eds), Women on Corporate Boards of Directors: Academic Press.

Winchester H. Chesterman, C., Lorenzo, S. and Browning, L. (2005), The Great Barier Universities, Australian Vice-Chancellors' Committee.

Universities, Australian Vice-Chancellors' Committee.
Vinslow, S. (2005), 'Work-family conflict, gender, and parenthood, 1977-1997', Journal of Family Issues, 26(6), 727-55. 